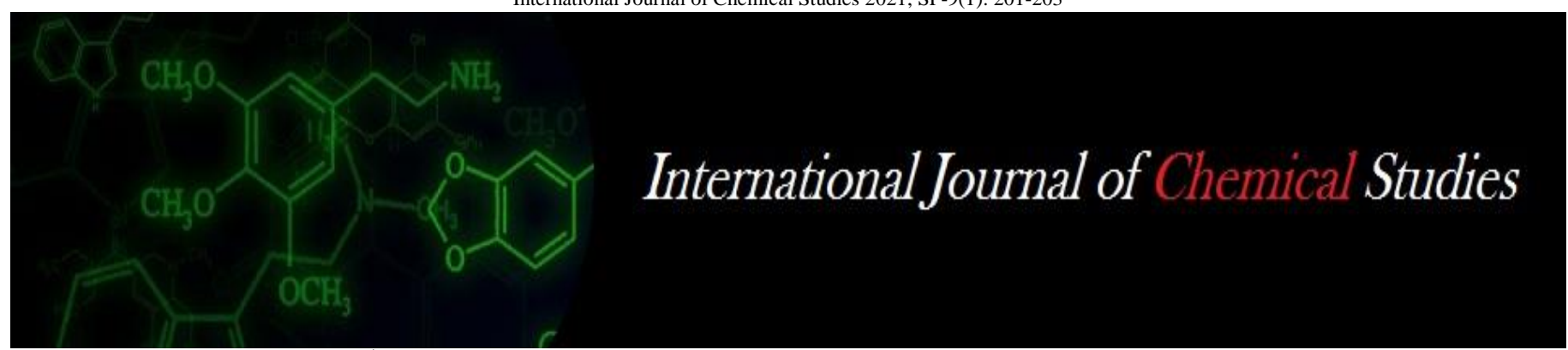

P-ISSN: 2349-8528

E-ISSN: 2321-4902

www.chemijournal.com

IJCS 2021; SP-9(1): 201-203

(C) 2021 IJCS

Received: 17-11-2020

Accepted: 26-12-2020

\section{Ambika Sharma}

Department of Veterinary

Biochemistry, College of

Veterinary Science and Animal

Husbandry, DUVASU, Mathura,

Uttar Pradesh, India

\section{Rajesh Nigam}

Department of Veterinary

Biochemistry, College of

Veterinary Science and Animal

Husbandry, DUVASU, Mathura,

Uttar Pradesh, India

\section{Dr. Ashish Kumar}

Ph.D., Scholar, Department of Biochemistry, All India Institute of Medical Sciences, Rishikesh,

Uttarakhand, India

\section{Abhishek Pal}

Department of Veterinary

Biochemistry, College of

Veterinary Science and Animal

Husbandry, DUVASU, Mathura,

Uttar Pradesh, India

Vaibhav Tomar

College of Biotechnology,

DUVASU, Mathura, Uttar

Pradesh, India
Corresponding Author:

Dr. Ashish Kumar

Ph.D., Scholar, Department of Biochemistry, All India Institute

of Medical Sciences, Rishikesh,

Uttarakhand, India

\section{SDS-PAGE analysis of urinary peptides in indigenous cow}

\author{
Ambika Sharma, Rajesh Nigam, Ashish Kumar, Abhishek Pal and \\ Vaibhav Tomar
}

DOI: https://doi.org/10.22271/chemi.2021.v9.i1d.11580

\begin{abstract}
Urinary proteins and peptides are biologically active molecules with diverse structural and antimicrobial properties for combating infections and microbial drug resistance. The aim of this study was to identify the proteins excreted in cow urine. In the present study, fresh urine samples were collected from ten healthy cycling indigenous cows and urinary proteins and peptides were extracted using ion exchange chromatography. Extracted urinary proteins and peptides of healthy cow were analyzed by a combination of SDS-polyacrylamide gel electrophoresis and coomassie brilliant blue stain. We have been able to identify multiple protein bands from cow urine with a molecular weight ranging from $22-153 \mathrm{kDa}$.
\end{abstract}

Keywords: Urinary peptides, cow urine, SDS-PAGE, chromatography

\section{Introduction}

Urine contains proteins and peptides which are either generated in the urinary tract and have specific functions there, or are the filtered or secreted by-products of physiological events taking place in the organism. With the exposure of the urinary tract to a variety of microbes, urine contains antimicrobial peptides which may play a role in local host defence ${ }^{[1,2]}$. The urinary proteome is very dynamic and responsive not only to disease conditions but also to seasonality ${ }^{[3]}$. Because of the emergence of bacterial resistance to antibiotics, extensive search for alternatives to synthetic antibiotics has begun. Antimicrobial peptides represent a promising class of natural antibiotics that has not been extensively exploited yet. AMPs are expressed in many tissues and even urine. Urine of several domestic animals is of therapeutic value in Unani medicine ${ }^{[4]}$ but Go-Mutra (Cow urine) is described as the best of all types of animal urine ${ }^{[5]}$. In ancient Indian literature, 'Sushrita Samhita' and 'Ashtanga Sangraha', cow urine has been described as the most effective secretion of animal origin with innumerable therapeutic values ${ }^{[6]}$. Nearly 1550 urinary proteins were identified and profiled from the Karan Fries cows ${ }^{[7]}$. The antibacterial activity of urinary antimicrobial peptides from cow urine was demonstrated against the E. Coli and Staphylocoocus aureus by ${ }^{[8]}$. The aim of the present study was to extract and characterize anionic proteins and peptides from the indigenous cow urine.

\section{Material and Methods}

\section{Collection and preparation of urine samples}

Early morning mid-stream urine was collected from ten healthy cycling indigenous cows from the Instructional Livestock Farm Complex of Veterinary College, Mathura, maintained under the intensive system. Freshly collected urine samples were filtered using $0.2 \mu \mathrm{m}$ membrane filter and diafiltered using $10 \mathrm{kDaAmicon}$ Ultra-4 Centrifugal Filter Unit with the Ultracel-10 membrane (Millipore) by centrifugation at $4000 \mathrm{~g}$ for 20 minutes.

\section{Extraction of anionic fractions by ion exchange chromatography}

Peptide fractions were extracted from diafiltered urine using weak cation exchanger beads (Macro Prep®CM Resin, BIO-RAD, India) using method described by Valore et al. (1998) with slight modification. The anionic fractions were separated by washing the beads with approximately two bed volume of $25 \mathrm{mM}$ ammonium acetate( $\mathrm{pH}-7.5)$ by centrifugation at 
$200 \mathrm{~g}$ for 10 minutes. This step of washing was repeated five times to ensure effective removal of anionic proteins. Protein quantification was done in extracted fractions using Lowry method (Lowry et al., 1951).

\section{SDS-PAGE}

Urine proteins were fractionated by SDS-PAGE using $12.5 \%$ resolving gel and 5\% stacking gels ${ }^{[9]}$, with a Mini Protean Tetra Cell system (Bio-Rad, USA). A molecular weight marker was run (Bangalore Genei, $250 \mathrm{kDa}-10 \mathrm{kDa}$ ) along with urine sample. The amount of protein loaded was $5 \mu \mathrm{g}$ per sample. Gel was stained with Coomassie brilliant blue R-250 staining solution kit (Bio-Rad, USA) and were analysed with a gel documentation system (Bio-rad, USA). The graphic representations and molecular weights of the bands for each lane were obtained using Image $\mathbf{J}$ software.

\section{Results and Discussion}

The aim of this study was to identify the proteins excreted in the urine. Since sodium dodecyl sulfate polyacrylamide gel electrophoresis (SDS-PAGE) allows excellent separation of proteins according to their molecular weights ${ }^{[10]}$, this technique was used for analysing the urinary proteins in healthy cows. Although urine is abundant and easy to collect, it is a challenging sample for proteomics studies. The interfering salts and other contaminants can reduce the efficiency of extraction. Obtaining pure protein samples from urine, without sample loss can be difficult and a major impediment to a successful gel-free approach ${ }^{[11]}$. Numerous protocols have been employed to concentrate and purify urinary proteins; e.g. Lyophilisation ${ }^{[12]}$, precipitation ${ }^{[13]}$, ultracentrifugation ${ }^{[14]}$ and centrifugal filtration ${ }^{[15]}$. We developed a protocol in our laboratory by combining ultrafiltration and ion exchange chromatography for extracting cow urinary protein in good amount.

The urinary protein concentrations were distributed normally in the extracted anionic fractions. The lowest protein concentration measured was $1.56 \mu \mathrm{g} / \mu \mathrm{l}$, the highest, 1.8 $\mu \mathrm{g} / \mu \mathrm{l}$. SDS-PAGE separated protein primarily on the basis of mass. Cow urinary proteins were subjected to SDS-PAGE and compared with the molecular markers ranged from $250 \mathrm{kDa}$ to $10 \mathrm{kDa}$. The gels were analyzed in gel documentation system to determine the relative molecular weight of protein bands of sample appeared on the gel. Representative gels and pherograms of anionic fraction of urine samples from cows are reported in Figure 1. We separated 12 protein bands in the urine of cows. The exact molecular weights were 153.4, 84.0, 72.0, 66.6, 62.7, 58.2, 42.6, 38.1, 28.2, 22.1, 18.1 and 16.8 . The majority had a molecular weight (MW) between 22 and $75 \mathrm{kDa}$. Similar study reported in cows found $13 \pm 5$ protein bands in the urine ${ }^{[16]}$. Two proteins between 16-18 $\mathrm{kDa}$ was also identified but it has been reported that the proteins with molecular weight less than $20 \mathrm{kDa}$ cannot be reliably separated by SDS PAGE [17, 18], therefore we have not considered those bands in our study.

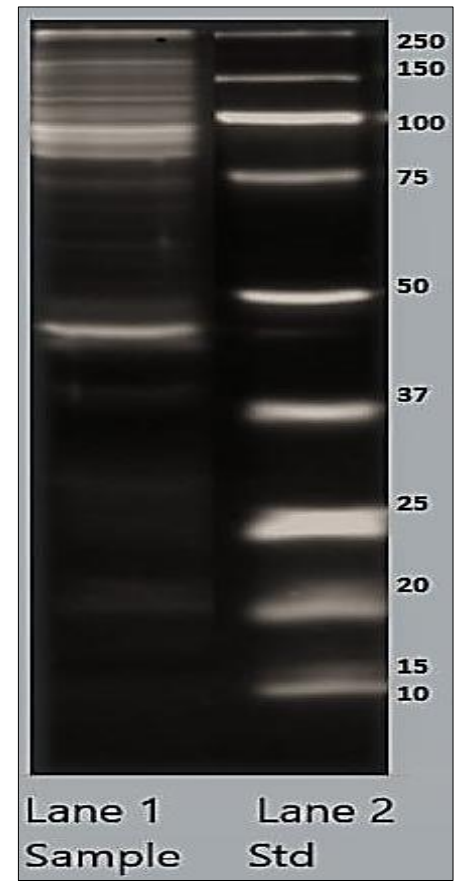

Fig 1: SDS-PAGE of anionic fractions of cow urine

For healthy cattle the urinary protein pattern depended neither on the urine sampling technique (catheterization, spontaneous urine) nor on the reproductive stage ${ }^{[17]}$. In a study with nonpregnant cow urine, three protein bands were found with molecular weights of $67.57,62.27$ and $55.04 \mathrm{kDa}{ }^{[19]}$. A similar study was carried out in non-pregnant cow urine by ${ }^{[20]}$, where she found bands of $69,63,50,38,34,25$ and 13 $\mathrm{kDa}$. A $12 \mathrm{kDa}$ molecular weight protein was separated as a single band on SDS-PAGE from the cow urine (Kawamura et al., 1990).

By performing urinary electrophoresis, the proteins with different molecular weight could be identified. The mechanism of excretion of high molecular weight proteins (Albumin, Tf, IgG) and proteins smaller than the albumin in urine has been well established as a consequence of which only small amounts of serum proteins are excreted in the urine. The highest percentage of protein found in the urine had molecular weight of approximately $84 \mathrm{kDa}$. Other LMW proteins in the cow urine were at $22,28,38,42$ and $58 \mathrm{kDa}$ while the HMW protein was at $153 \mathrm{kDa}$. The 55-65 bands may be $\alpha 1$ - antitrypsin while the band near $45 \mathrm{kDamay}$ be heavy chain IgG or IgA (Outteridge, 1985). Analysis of protein precipitated by sodium chloride using SDS-PAGE revealed a prominent high molecular weight band at the level 
of $85 \mathrm{kDa}$ (Uromodulin) in coomassie stained gels in Buffaloes ${ }^{[21]}$. The total protein yielded from SDS-PAGE and expressed as electrophoretic urinary total protein creatinine (E-UTPC) ratio was determined in urine of dogs ${ }^{[22]}$ and they found that the urine proteins are distributed from molecular weight $10 \mathrm{kDa}$ to $80 \mathrm{kDa}$.

\section{Acknowledgement}

The authors are grateful to the Vice chancellor, Veterinary University (DUVASU), Mathura-281001, (UP) India for providing necessary facilities.

\section{References}

1. Hancock REW, Scott MG. The role of antimicrobial peptides in animal defenses. Proc Natl Acad Sci 2000;97(16):8856-8861. DOI:10.1073/pnas.97.16.8856

2. Zasloff M. Antimicrobial Peptides, Innate Immunity, and the Normally Sterile Urinary Tract. J Am Soc Nephrol 2007;18(11):2810-2816. DOI:10.1681/ASN.2007050611

3. Kalantari S, Jafari A, Moradpoor R, Ghasemi E, Khalkhal E. Human Urine Proteomics: Analytical Techniques and Clinical Applications in Renal Diseases. Int J Proteomics 2015;2015:1-17. DOI: $10.1155 / 2015 / 782798$

4. Vohora SB, Khan SY. Animal Origin Drugs Used in Unani Medicine. Vikas Publishing House, New Delhi India 1979, P1-137.

5. Pandey GS. CK Bhav Prakash Nighantu (Indian Materia Medica) of Sri Bhavamisra (c.1600-1600 AD). In: Ath Mutravargh. Varanasi: Chaukhamba Bharati Academy 2009;18:778.

6. Chauhan RS, Garg N. Cow Therapy as an Alternative to Antibiotic. Indian Science Congress, Bangalore, Karnataka, India 2003.

7. Bathla S, Rawat P, Baithalu R et al. Profiling of urinary proteins in Karan Fries cows reveals more than 1550 proteins. J Proteomics 2015;127:193-201. DOI:10.1016/j.jprot.2015.05.026

8. Sharma A, Nigam R, Kumar A, Singh S. Mass Spectrometry-Based Identification of Urinary Antimicrobial Peptides in Dairy Cows. Protein Pept Lett 2020;27(3):225-235.

DOI:10.2174/0929866526666191025105038

9. Laemmli UK. Cleavage of Structural Proteins during the Assembly of the Head of Bacteriophage T4. Nature 1970;227(5259):680-685. DOI:10.1038/227680a0

10. Shapiro AL, Viñuela EV, Maizel J. Molecular weight estimation of polypeptide chains by electrophoresis in SDS-polyacrylamide gels. Biochem Biophys Res Commun 1967;28(5):815-820. DOI:10.1016/0006291X(67)90391-9.

11. Vaezzadeh AR, Deshusses JMP, Waridel $\mathrm{P}$ et al. Accelerated digestion for high-throughput proteomics analysis of whole bacterial proteomes. J Microbiol Methods 2010;80(1):56-62. DOI:10.1016/j.mimet.2009.10.019

12. Lee RS, Monigatti F, Briscoe AC, Waldon Z, Freeman MR, Steen H. Optimizing Sample Handling for Urinary Proteomics. J Proteome Res 2008;7(9):4022-4030. DOI:10.1021/pr800301h

13. Orenes-Piñero E, Cortón M, González-Peramato $\mathrm{P}$ et al. Searching Urinary Tumor Markers for Bladder Cancer Using a Two-Dimensional Differential Gel Electrophoresis (2D-DIGE) Approach. J Proteome Res 2007;6(11):4440-4448. DOI:10.1021/pr070368w
14. Lafitte D, Dussol B, Andersen S et al. Optimized preparation of urine samples for two-dimensional electrophoresis and initial application to patient samples. Clin Biochem 2002;35(8):581-589. DOI:10.1016/S00099120(02)00362-4

15. Thongboonkerd V, Chutipongtanate S, Kanlaya R. Systematic Evaluation of Sample Preparation Methods for Gel-Based Human Urinary Proteomics: Quantity, Quality, and Variability. J Proteome Res 2006;5(1):183191. DOI:10.1021/pr0502525

16. Ferlizza DE. Urine proteome in animals of veterinary interest: species comparison and new biomarkers of nephropathy, $\mathrm{PhD}$ Thesis, Submitted to University of Bologna, Italy 2015.

17. Graber HU, Martig J. Urinary Protein Analysis in Cardiomyopathy-Affected and Healthy Cattle by SDSPolyacrylamide Gel Electrophoresis. J Vet Med Ser A 1992;39(1-10):769-776. 0442.1992.tb00242.x

18. Kshirsagar B, Wiggins RC. A map of urine proteins based on one-dimensional SDS-polyacrylamide gel electrophoresis and Western blotting using one microliter of unconcentrated urine. Clin Chim Acta 1986;158(1):1322. DOI:10.1016/0009-8981(86)90111-7

19. Nirmala GC. Studies on pharmacological activities and safety evaluation of Deoni cows' urine in laboratory animals. PhD thesis, submitted to Karnataka Veterinary, Animal and Fisheries Sciences University, Bidar 2009.

20. Amita G. Effect of cow's urine on health of rats, PG Thesis submitted to Chandrashekhar Azad University of Agriculture and Technology, Kanpur, Uttar Pradesh, India.

21. Sudha MR, Kalyani P, Ashok V. Isolation of normal buffalo urinary proteins. Int J Pharm Bio Sci 2012;3(3):B 49-57.

22. Jaturakan O, Vanichwatanaramlouk M, Kornkaew A et al. SDS-PAGE Electrophoresis for Urinary Protein Analysis in Dogs with Chronic Kidney Disease and Urinary Tract Infection. Thai J Vet Med 2013;43(1):7583. 